\title{
Safety Disposal of Rice Straw by Biodegradation Using Streptomyces Tendae
}

Fahad Al-Dhabaan

check for

updates

Citation: Al-Dhabaan, F. Safety

Disposal of Rice Straw by

Biodegradation Using Streptomyces

Tendae. Sustainability 2021, 13, 13640.

https://doi.org/10.3390/

su132413640

Academic Editor: Flavio Boccia

Received: 26 October 2021

Accepted: 6 December 2021

Published: 10 December 2021

Publisher's Note: MDPI stays neutral with regard to jurisdictional claims in published maps and institutional affiliations.

Copyright: (C) 2021 by the author. Licensee MDPI, Basel, Switzerland. This article is an open access article distributed under the terms and conditions of the Creative Commons Attribution (CC BY) license (https:// creativecommons.org/licenses/by/ $4.0 /)$.
Department of Biology, Science and Humanities College, Shaqra University, Al-Quwayiyah 11961, Saudi Arabia; microbiologyexpert@outlook.com; Tel.: +996-504893691

\begin{abstract}
Rice straw is a byproduct formed during rice cultivation. Disposal of rice straw may happen via unhygienic methods such as burning, which is happening in Malaysia and other countries. This study aims to rid rice straw via an eco-friendly biodegradation technique. Biodegradation of rice straw depended on actinobacteria, which were isolated from the cultivated soil of rice and rhizosphere areas in Tabuk region. Out of thirty actinobacterial isolates, only three isolates (S-5, S-12, S-20) biodegraded starch, cellulose, lignin and rice straw powder. The most potent actinobacterial isolate (S-5) was identified as Streptomyces tendae, which effectively biodegraded all polysaccharides of rice straw. Biodegradation of rice straw was associated with a significant reduction in $\mathrm{C} / \mathrm{N}$ ratio, where the latter fell from $30.4 \%$ to $17.2 \%$ within $42 \mathrm{~d}$.
\end{abstract}

Keywords: actinobacteria; biotransformation; hydrolytic enzymes; ligninolytic activity

\section{Introduction}

Actinobacteria are sporulating, aerobic, and Gram-positive microorganisms, which are characterized by a high $G+C$ content $[1,2]$. Actinobacteria are filamentous due to formation of both branched aerial and substrate mycelia [3]. Despite actinobacteria living in different habitats, the soil is still the mother, and its odor is usually present [4]. Actinobacteria are widely used in various industries, including the biotransformation industry due to its production of different bioactive metabolites such as lignocellulases [5]. Lignocellulases is a set of hydrolytic enzymes including amylases, cellulases, hemicellulases and lignolytic enzymes, which hydrolyze starch, cellulose, hemicellulose and lignin, respectively [6]. Pectin and lignocellulose are the main components of the plant cell walls as well as cellulose, hemicellulose and lignin [7,8]. Cellulases are used in various industrial applications, such as bioethanol, biomethane, textile, pulp, paper and detergent industries [9-11]. Hemicellulases are widely used in the industries of bio-bleaching, deinking, clarification of fruit juices, feed upgradation, fodder and fibers, and saccharification of hemicelluloses to xylose sugars [12]. Lignolytic enzymes are using as bioreactors in the biofuel, paper, textile, food, cosmetic and pharmaceutical industries as well as other applications such as wastewater treatment, bioremediation and organic synthesis [13]. Although different microorganisms are produced for lignocellulases, actinobacteria are still the most potent producers [14,15].

Rice cultivation is prevalent worldwide (148 million hectares) due to its high economic importance and vital role in food security. Unfortunately, rice crop is associated with the undesirable organic substance called rice straw, which occupies a wide area in the field. This substance is an undesirable byproduct due to its slow degradation rate, poor digestibility, weak proteinaceous content, and wealth of lignin and silica, which also harbor diseases [16]. Although rice straw is now widely used in compost production in many countries, the biological treatment of rice straw is urgently needed to avoid environmental pollution. Burning rice straw is leading to environmental pollution and respiratory diseases resulting from the harmful fumes emitted through burning [17]. The biological treatment of rice straw depends on using some microorganisms such as actinobacteria, which feed on rice straw and produce useful primary and secondary metabolites such as biofuel, sugars 
and pharmaceutical products [18]. The in situ biodegradation of rice straw raises the soil fertility due to liberation of carbon sources such as sugars and oligosaccharides without any harmful effect [19]. Thermophilic actinobacteria produce hydrolytic enzymes with unique properties, by which they effectively hydrolyze the recalcitrant polysaccharides of rice straw and release soluble carbohydrates [20]. The mesophilic phase of carbohydrate utilization is managed by fungi and eubacteria, while the thermophilic phase is usually occupied with actinobacteria due to decomposition of complex substances to available forms, such as lignin-containing wastes [21]. Therefore, pre-inoculation of rice straw bulk by actinobacteria leads to fast and efficient composting. This study aims to rid undesirable rice straw using an eco-friendly solution and obtaining useful products during hydrolysis of lignocelluloses.

\section{Materials and Methods}

Sampling and isolation of actinobacteria

Sampling was carried out from cultivated soil in rice and rhizosphere areas in Tabuk region. Sampling occurred at a depth of $5.0 \mathrm{~cm}$, pooled in sterilized concerned-purpose containers, and maintained at $4.0^{\circ} \mathrm{C}$. The samples of rice straw were air-dried and grinded to obtain a powder. Manure and rice straw (1:1) were added to the water and agitated thoroughly until $60 \%$ moisture was measured by a humidity meter. The mixture was placed in a covered, pored container to prevent the changing of temperature and humidity. The sludge was recycled every day for three weeks, and then one time every week. Replication was carried out four times, the temperature was recorded daily, and the sampling was carried out weekly.

Isolation of actinobacteria

A mixture of the sample $(10 \mathrm{~g})$ and sterile distilled water $(90 \mathrm{~mL})$ was formed in $250 \mathrm{~mL}$ Erlenmeyer flasks. The mixture was stirred thoroughly $(150 \mathrm{rpm})$ for an hour. The mixture was serially diluted $\left(10^{-2}-10^{-5}\right)$. One hundred microliters was pipetted and dropped onto the agar surface of actinobacterial selective medium (Difco). The agar plates were inversely incubated at $28{ }^{\circ} \mathrm{C}$ for $14 \mathrm{~d}$ and examined daily. The separated colony was picked up by a sterile loop and streaked onto the agar surface of the selective medium. The inoculated plates were inversely incubated at $28^{\circ} \mathrm{C}$ for $14 \mathrm{~d}$ and examined daily.

Screening test of polysaccharides

Starch hydrolysis

An amended actinobacterial selective medium $(\mathrm{pH} 7.9 \pm 0.2)$ containing $10 \%$ starch was used. The inoculation of the solid medium was performed by $3.0 \mu \mathrm{L}$ equivalent to $108 \mathrm{cfu} \mathrm{mL}^{-1}$ of actinobacterial suspension. The agar plates were incubated at $28 \pm 2{ }^{\circ} \mathrm{C}$ for $72 \mathrm{~h}$. The bacterial growth was flooded by iodine solution (10\%) for $30 \mathrm{~s}$. The areas of blue color referred to unhydrolyzed starch, while the clear zone surrounding the bacterial growth referred to starch hydrolyzed by amylases.

Cellulose hydrolysis

Cellulose hydrolysis activity was tested on the agar surface of Jensen's medium (20 g sucrose, $1.0 \mathrm{~g}$ potassium hydrogen orthophosphate, $0.1 \mathrm{~g}$ ferrous sulphate, $0.5 \mathrm{~g}$ hydrous magnesium sulphate, $0.5 \mathrm{~g}$ sodium chloride, $0.005 \mathrm{~g}$ sodium molybdate, $2.0 \mathrm{~g}$ calcium carbonate, $15.0 \mathrm{~g}$ agar, $2.0 \mathrm{~g}$ carboxymethyl cellulose and $1.0 \mathrm{~L}$ distilled water, $\mathrm{pH} 7.5 \pm 0.2)$ [22]. The agar surface was streaked with $3.0 \mu \mathrm{L}$ bacterial suspension and then incubated at $28 \pm 2{ }^{\circ} \mathrm{C}$ for $72 \mathrm{~h}$. The bacterial growth was flooded with Congo red solution for $15 \mathrm{~min}$ and then discarded. Sodium chloride $(1.0 \mathrm{M})$ was poured on the bacterial growth for $15 \mathrm{~min}$. The clear zone surrounding the bacterial growth referred to hydrolyzed cellulose. A qualitative assay of cellulose hydrolysis activity was carried out by measuring the clear zone diameter [23].

Lignin hydrolysis

The lignin hydrolysis activity was tested on the agar surface of the modified medium ( $1.0 \mathrm{~g}$ ammonium hydrogen orthophosphate, $0.2 \mathrm{~g}$ potassium chloride, $0.2 \mathrm{~g}$ hydrous magnesium sulphate, $2.0 \mathrm{~g}$ yeast extract, $2.0 \mathrm{~g}$ glucose, $0.1 \mathrm{~g}(0.01 \% \mathrm{w} / \mathrm{v})$ azure $\mathrm{B}, 15 \mathrm{~g}$ agar, 
and 1.0 L distilled water, $\mathrm{pH} 7.5 \pm 0.2$ ). The agar surface was streaked with $3.0 \mu \mathrm{L}$ bacterial suspension and then incubated at $28 \pm 2{ }^{\circ} \mathrm{C}$ for $72 \mathrm{~h}$. The bacterial growth was flooded by iodine solution $(10 \%)$ for $10 \mathrm{~min}$. The clear zone surrounding the bacterial growth referred to hydrolyzed lignin [24].

Screening test

The three most potent actinobacterial isolates (S-5, S-12 and S-20) were tested to degrade the rice straw at different percentages (0, 10, 20 and 25\%) using the modified medium at $\mathrm{pH} 7.5-8.1 \pm 0.2$. The autoclaved medium was poured in Petri plates and then inoculated with $3.0 \mu \mathrm{L}$ bacterial suspension. The plates were inversely incubated at $28 \pm 2{ }^{\circ} \mathrm{C}$ for $72 \mathrm{~h}$.

Identification of the most potent actinobacteria

The identification of actinobacterial isolate (S-5) was carried out by both classical and genetical techniques [25]. Inorganic salt starch agar medium (ISP-4) was used to take an electron micrograph where the medium was inoculated and incubated for $7.0 \mathrm{~d}$ at $35^{\circ} \mathrm{C}$. A bacterial growth was scratched, fixed in glutaraldehyde $(2.5 \% v / v)$, washed with water, and finally fixed in osmium tetraoxide $(1.0 \% w / v)$ for an hour. The prepared specimen was washed twice with water and then dehydrated in ethanol. The specimen was dried in a drying apparatus (Polaron E3000), coated in gold, and examined in a JEOLISM 541OLV scanning electron microscope at $15 \mathrm{kv}$.

Genetical identification of the most potent actinobacteria

Genetical identification was carried out by determining the sequence of the $16 \mathrm{~S}$ rRNA gene, which was amplified in a thermocycler (Perkin Elmer Cetus Model 480) using universal primers of $27 \mathrm{f}$ ( $5^{\prime}$-AGA GTT TGA TCC TGG CTC AG-3') and 1525r (5'-AAG GAG GTG ATC CAG CC-3') under the following conditions: $94{ }^{\circ} \mathrm{C}$ for $5.0 \mathrm{~min}, 35$ cycles of $94{ }^{\circ} \mathrm{C}$ for $60 \mathrm{~s}, 55$ for $60 \mathrm{~s}, 72{ }^{\circ} \mathrm{C}$ for $90 \mathrm{~s}$ and final extension at $72{ }^{\circ} \mathrm{C}$ for $5.0 \mathrm{~min}$. The product was directly sequenced using a BigDye terminator cycle sequencing kit (PE Applied Biosystems USA) on an ABI 310 automated DNA sequencer (Applied Biosystems, Waltham, MA, USA). Homology of the $16 \mathrm{~S}$ rRNA sequence was analyzed using the BLAST program from the GenBank database [26].

Evaluation of the most potent isolate (S-5)

The rice straw was grinded and sieved to obtain a powder, which then was mixed thoroughly with manure $(1: 1, w / w)$ and sterile distilled water with hard agitation until $60 \%$ moisture was attained. The sludge was inoculated with $3.0 \mu \mathrm{L}$ bacterial suspension and then transferred into plastic bags $(150 \mathrm{~g} / \mathrm{bag})$, which were incubated at $28{ }^{\circ} \mathrm{C}$ for 6.0 weeks. These bags were aerated by recycling every week. The collection of specimens was carried out on the third and sixth weeks of the composting process. Non-inoculated sludge served as a negative control [27].

Determination of the $\mathrm{C} / \mathrm{N}$ ratio

The $\mathrm{C} / \mathrm{N}$ ratio of decomposed sludge was determined during each sampling time. The weight of the sludge was recorded before and after ignition at $500{ }^{\circ} \mathrm{C}$ for $4.0 \mathrm{~h}$. The difference between the two weights expressed the amount of organic matter. The total carbon and nitrogen contents were measured using the digestion method [28-30].

Analysis of cellulose, hemicelluloses and lignin content

The content of cellulose, hemicelluloses and lignin was analyzed using neutral detergent fiber (NDF) and acid detergent fiber (ADF) methods [31].

\section{Results and Discussion}

Thirty unrepeated actinobacteria were isolated from cultivated soil in rice and rhizosphere areas in Tabuk region. The lignocellulolytic activity was screened against starch, cellulose and lignin, as shown in Table 1 . Only three actinobacteria (S-5, S-12, S-20) produced lignocellulolytic activity, and actinobacterium assigned as S-5 provided the highest activity and was selected as the most potent one. Nigam and Singh [32] reported that recalcitrant substrates such as starch, cellulose and lignin were completely degraded by the hydrolytic enzymes of actinobacteria. The starch composition relatively differed from 
other polysaccharides, where starch composed of amylose and amylopectin are built from $\alpha$-D-glucose units.

The most potent lignocellulolytic actinobacterium (S-5) is typically identified as Streptomyces tendae by determination of classical and genetical features. Cultural characteristics were determined by describing the bacterial growth on seven microbiological cultural media: tryptone yeast extract broth, yeast-malt extract agar, oat-meal extract agar, inorganic salt starch agar, glycerol asparagine agar, peptone yeast extract iron agar and tyrosine agar, as shown in Table 2. Morphological characteristics, including spiral spore chain and warty surface of spores, were determined as shown in Figure 1. The biochemical and physiological characteristics were determined as shown in Table 3. Bacterial identification was confirmed by $16 \mathrm{~S}$ rRNA gene sequencing using the PCR technique, which revealed that $98 \%$ similarity, as shown in Figure 2, was observed between the actinobacterial isolate (S-5) and S. tendae M23 with accession number HM594286.1 in GenBank [33].

Rice straw was used as a main carbon source and as a test substrate to evaluate the lignocellulolytic activity of actinobacteria (S-5, S-12, S-20). All isolates were found to have good growth with $25 \%$ of rice straw powder in the medium, but only one actinobacterium (S-5) had been adapted to 35\%. Actinobacterium (S-5) was found have the largest clear zone on the agar surface of the medium containing rice straw powder $(35 \%)$. Compared with the control medium, actinobacterium (S-5) efficiently consumed the rice straw powder due to production of lignocellulolytic enzymes. McCarthy [34] and Abdulla and El-Shatoury [35] reported that actinobacteria were the best bio-machine for degradation of large and complex molecules due to secretion of a wide array of hydrolytic enzymes, so they were very useful for the soil during the composting process. Actinobacteria were used in the biodegradation of rice straw, and the maximum concentration of treatment $(25 \%)$ was reasonable because most actinobacterial isolates (A2, A4 and A24) did not pass $20 \%$, except actinobacterial isolates A7 and A9. Sewage sludge (25\%) was used to test potential lignocellulose hydrolyzing fungi [36].

Compared with control, biodegradation of rice straw by S. tendae (S-5) for $21 \mathrm{~d}$ was associated with reduction in cellulose, hemicellulose, lignin and carbon content. After $42 \mathrm{~d}$, there was a difference between the contents of cellulose, hemicelluloses and carbon of the test and control. Lignin was biodegraded in the early stage by S. tendae (S-5) during the composting process and was then followed by other polysaccharides, so their contents were found to be low in the last stage [37]. Cellulases and hemicellulases were numerous, including endoglucanase, exoglucanase, $\beta$-glucosidase, xylanase and cellobiohydrolase $[38,39]$.

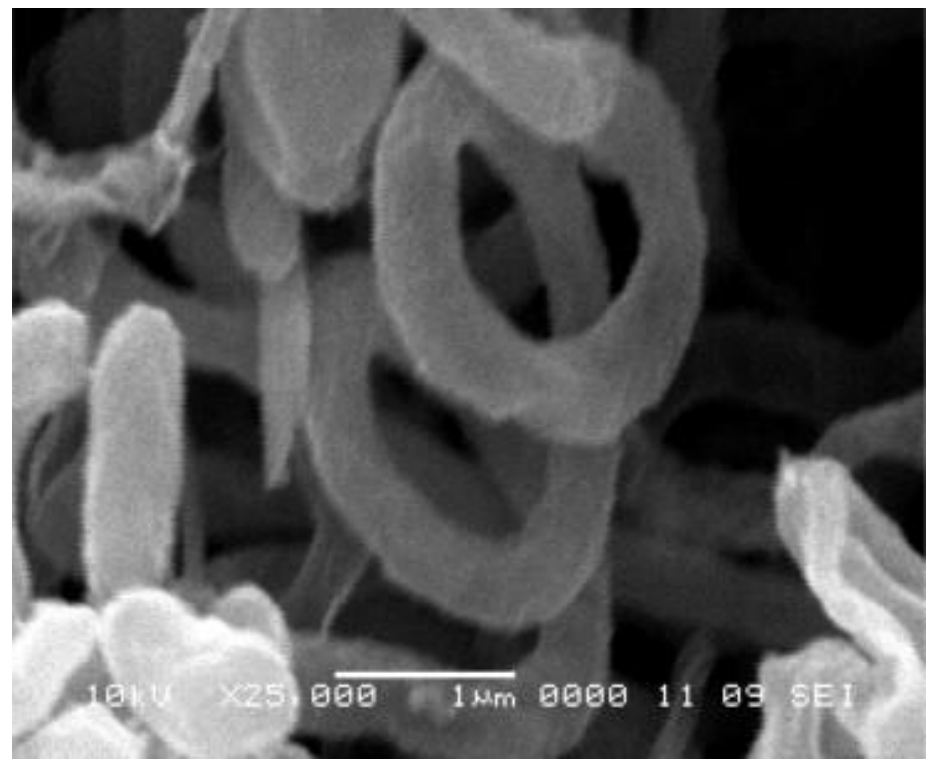

Figure 1. Scanning electron micrograph of the actinobacterial isolate S-5. 
During the first days of rice straw biodegradation, the total carbon content decreased in both test and control. Carbon compounds are very essential for microbes because they are used as a main energy source. Carbon dioxide is an end-product of carbon catabolism during the composting process, while the nitrogen content increased due to anabolism of different bioactive substances $[40,41]$. During composting, the $\mathrm{C} / \mathrm{N}$ ratio reduced, and after $42 \mathrm{~d}$ the $\mathrm{C} / \mathrm{N}$ ratio was 17.2. Different species of Streptomyces and Micromonospora were reported in many studies as the most potent destructive actinobacteria for lignocellulose wastes in aerobic conditions $[42,43]$.

Table 1. Screening of lignocellulolytic activity of actinobacterial isolates.

\begin{tabular}{cccc}
\hline \multirow{2}{*}{ Actinobacterial Isolates } & \multicolumn{3}{c}{ Mean of Hydrolytic Activity (mm) } \\
\cline { 2 - 4 } & Starch & Cellulose & Lignin \\
\hline S-1 to S-4 & No activity & No activity & No activity \\
\hline S-5 & 30 & 25 & 22 \\
\hline S-6 to S-11 & No activity & No activity & No activity \\
\hline S-12 & 25 & 20 & 20 \\
\hline S-13 to S-19 & No activity & No activity & No activity \\
\hline S-20 & 27 & 25 & 25 \\
\hline S-21 to S-30 & No activity & No activity & No activity
\end{tabular}

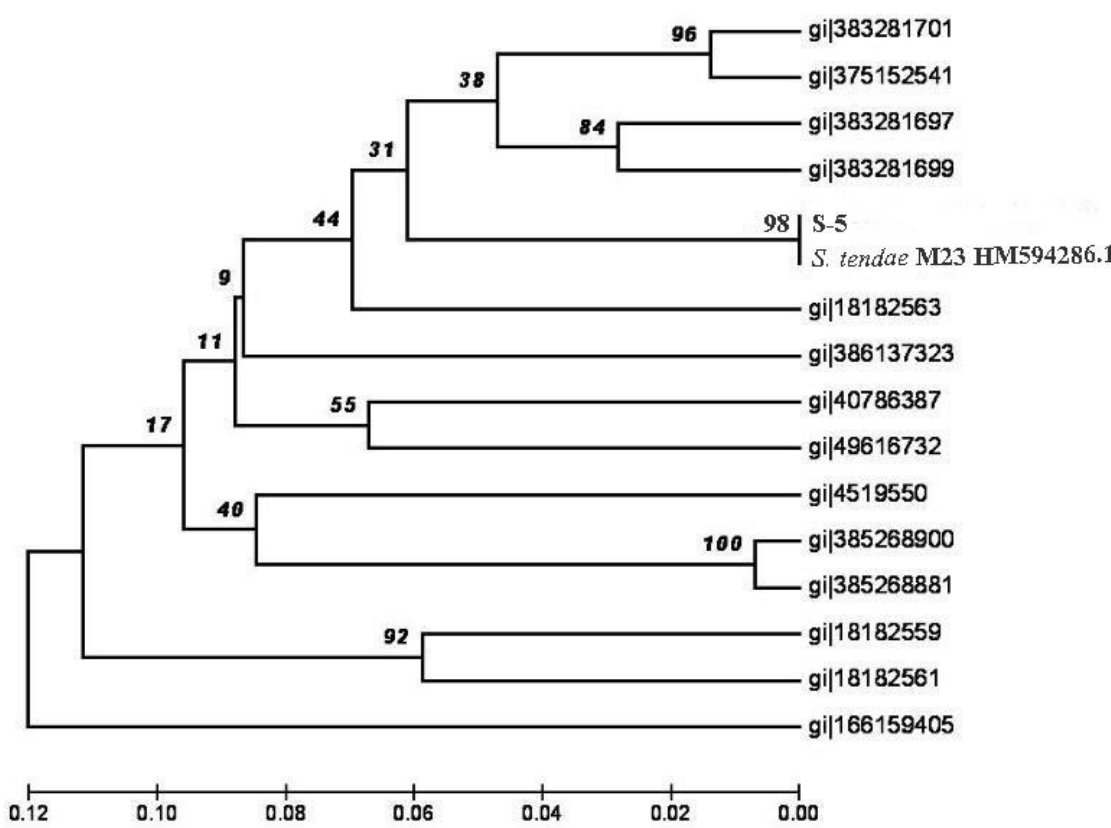

Figure 2. Phylogeny of the actinobacterial isolate S-5 for the isolated $16 \mathrm{~S}$ rRNA gene of $S$. tendae. The phylogeny was constructed based on the deduced amino acid sequences and using the Mega 3 programs. 
Table 2. Cultural characteristics of the actinobacterial isolate S-5.

\begin{tabular}{ccccc}
\hline \multirow{2}{*}{ Medium } & Growth & \multicolumn{3}{c}{ Color } \\
\cline { 3 - 5 } & & Aerial Mycelia & Substrate Mycelia & Diffusible Pigment \\
\hline TYEB & $\mathrm{P}$ & 264 L. Gray & 79 l.gy. YBr & None \\
\hline YMEA & $\mathrm{M}$ & 10 Pk Gray & 70 l. oy & None \\
\hline OMEA & $\mathrm{G}$ & 263 L. Gray & $761 . \mathrm{yBr}$ & 79 l.gy. YBr \\
\hline ISSA & $\mathrm{M}$ & 10 Pk Gray & 79 l.gy. YBr & None \\
\hline GAA & $\mathrm{G}$ & 264 L. Gray & 79 l.gy. YBr & None \\
\hline PYEIA & $\mathrm{P}$ & 10 Pk Gray & 79 l.gy. YBr & None \\
\hline TA & $\mathrm{P}$ & 10 Pk Gray & 79 l.gy. YBr & None \\
\hline
\end{tabular}

${ }^{1}$ TYEB; tryptone yeast extract broth, ${ }^{2}$ YMEA; yeast-malt extract agar, ${ }^{3}$ OMEA; oat-meal extract agar ${ }^{4}$ ISSA inorganic salts starch agar ${ }^{5}$ GAA; glycerol asparagine agar ${ }^{6}$ PYEIA; peptone yeast-extract iron agar ${ }^{7}$ TA; tyrosine agar ${ }^{8} \mathrm{P}$; poor growth ${ }^{9} \mathrm{M}$; moderate growth ${ }^{10} \mathrm{G}$; good growth ${ }^{11} \mathrm{~L}$. Gray; light gray ${ }^{12}$ l.gy. YBr; light gray yellowish brown ${ }^{13} \mathrm{Pk}$. Gray; pinkish gray ${ }^{14} 1$. oy; light orange yellow ${ }^{15} 1$. yBr; light yellowish brown.

Table 3. Biochemical characteristics of the actinobacterial isolate S-5.

\begin{tabular}{ccc}
\hline Parameter & Test & Result \\
\hline Morphology & $\begin{array}{c}\text { Shape of spore chain } \\
\text { Color of spore mass } \\
\text { Motility }\end{array}$ & $\begin{array}{c}\text { Spiral } \\
\text { Gray }\end{array}$ \\
NM
\end{tabular}

${ }^{1} \mathrm{NM}$; non-motile. ${ }^{2} \mathrm{ND}$; not detected.

\section{Conclusions}

This study indicated that actinobacteria, especially Streptomyces spp, effectively biodegraded rice straw without emitting environmental pollution. Streptomyces bacteria produced a wide array of hydrolytic enzymes including amylases, cellulases, hemicellulases and lignases. These enzymes completely hydrolyzed the polysaccharides of rice straw and liberated free sugars, which supports soil fertility. The composting of rice straw in the presence of Streptomyces bacteria led to a reduction in the $\mathrm{C} / \mathrm{N}$ ratio.

Funding: This research received no external funding.

Institutional Review Board Statement: Not applicable.

Informed Consent Statement: Not applicable.

Data Availability Statement: Not applicable.

Acknowledgments: The author sincerely thanks the Head and members of Shaqra University and Head and members of Science and Humanities College for their great support to this work.

Conflicts of Interest: The author declares no conflict of interest. 


\section{References}

1. Chaudhary, H.S.; Soni, B.; Shrivastava, A.R.; Shrivastava, S. Diversity and versatility of actinomycetes and its role in antibiotic production. J. Appl. Pharm. Sci. 2013, 3, S83-S94.

2. Jeffrey, L.S.H. Isolation, characterization and identification of actinomycetes from agriculture soils at Semongok, Sarawak. Afr. J. Biotechnol. 2008, 7, 3700-3705.

3. Das, A.; Hamedani, K.; Soudbakhsh, M.; Prashanthi, K.; Bhattacharya, S.; Suryan, S. Enzymatic screening, antibacterial potential and molecular characterization of Streptomyces isolated from Wayanad District in Kerala, India. Int. J. Pharm. Bio Sci. 2012, 2, 201-210.

4. Das, P.; Solanki, R.; Khanna, M. Isolation and screening of cellulolytic actinomycetes from diverse habitats. Int. J. Adv. Biotechnol. Res. 2014, 5, 438-451.

5. Prakash, D.; Nawani, N.; Prakashetal, M. Actinomycetes: A repertory of green catalysts with a potential revenue resource. BioMed Res. Int. 2013, 2013, 264020. [CrossRef] [PubMed]

6. Mtui, G.Y.S. Lignocellulolytic enzymes from tropical fungi: Types, substrates and applications. J. Sci. Res. Essays 2012, 7, 1544-1555.

7. Isikgorand, F.H.; Becer, C.R. Lignocellulosic biomass: A sustainable platform for the production of bio-based chemicals and polymers. J. Polym. Chem. 2015, 6, 4497-4559. [CrossRef]

8. Limayem, A.; Ricke, S.C. Lignocellulosic biomass for bioethanol production: Current perspectives, potential issues and future prospects. Prog. Energy Combust. Sci. 2012, 38, 449-467. [CrossRef]

9. Deswal, D.; Sharma, A.; Gupta, R.; Kuhad, R.C. Application of lignocellulolytic enzymes produced under solid state cultivation conditions. Bioresour. Technol. 2012, 115, 249-254. [CrossRef]

10. Gupta, P.; Samant, K.; Sahu, A. Isolation of cellulose-degrading bacteria and determination of their cellulolytic potential. Int. J. Microbiol. 2012, 2012, 578925. [CrossRef]

11. Sukumaran, R.K.; Singhania, R.R.; Pandey, A. Microbial cellulases production, applications and challenges. J. Sci. Ind. Res. 2005, 64, 832-844.

12. Soni, H.; Kango, N. Hemicellulases in lignocellulose biotechnology: Recent patents. Recent Pat. Biotechnol. 2013, 7, 207-218. [CrossRef] [PubMed]

13. Abdel-Hamid, A.M.; Solbiati, J.O.; Cann, I.K.O. Insights into lignin degradation and its potential industrial applications. J. Adv. Appl. Microbiol. 2013, 82, 1-28.

14. de-Souza, W.R. Microbial degradation of lignocellulosic biomass. In Sustainable Degradation of Lignocellulosic Biomass-Techniques, Applications and Commercialization, 1st ed.; Chandel, E.D., Ed.; InTech E-Publishing Inc.: Rijeka, Croatia, 2013; Volume 3, pp. 120-142.

15. Kumar, R.; Biswas, K.; Soalnki, V.; Kumar, P.; Tarafdar, A. Actinomycetes: Potential bioresource for human welfare: A review. Res. J. Chem. Environ. Sci. 2014, 2, 5-16.

16. Kadam, K.L.; Forrest, L.H.; Jacobson, W.A. Rice straw as a lignocellulosic resource: Collection, processing, transportation, and environmental aspects. J. Biomass Bioenergy 2000, 18, 369-389. [CrossRef]

17. Kumar, A.; Gaind, S.; Nain, L. Evaluation of thermophilic fungal consortium for paddy straw composting. J. Biodegrad. 2008, 19, 395-402. [CrossRef] [PubMed]

18. Hatamoto, M.; Tanahashi, T.; Murase, J.; Matsuya, K.; Hayashi, M.; Kimura, M.; Asakawa, S. Eukaryotic communities associated with the decomposition of rice straw compost in a Japanese rice paddy field estimated by DGGE analysis. J. Biol. Fertil. Soils 2008, 44, 527-532. [CrossRef]

19. Tang, J.C.; Shibata, A.; Zhou, Q.; Katayama, A. Effect of temperature on reaction rate and microbial community in composting of cattle manure with rice straw. J. Biosci. Bioenergy 2007, 104, 321-328. [CrossRef] [PubMed]

20. Ball, A.S.; Godden, B.; Helvenstein, P.; Penninckx, M.J.; McCarthy, A.J. Lignocarbohydrate solubilization from straw by actinomycetes. Appl. J. Environ. Microbiol. 1990, 56, 3017-3022. [CrossRef] [PubMed]

21. Allgaier, M.; Reddy, A.; Park, J.I.; Ivanova, N.; D’haeseleer, P.; Lowry, S.; Sapra, R.; Hazen, T.C.; Simmons, B.A.; Vander-Gheynst, J.S.; et al. Targeted discovery of glycoside hydrolases from a switchgrass-adapted compost community. PLoS ONE 2010, 5, e8812. [CrossRef] [PubMed]

22. Jensen, H.L. Notes on the biology of Azotobacter. J. Appl. Microbiol. 2008, 14, 89-94. [CrossRef]

23. Teather, R.M.; Wood, P.J. Use of Congo red-polysaccharide interactions in enumeration and characterization of cellulolytic bacteria from the bovine rumen. J. Appl. Environ. Microbiol. 1982, 43, 777-780. [CrossRef]

24. Archibald, F.S. A new assay for lignin-type peroxidases employing the dye azure B. Appl. J. Environ. Microbiol. 1992, 58, 3110-3116. [CrossRef] [PubMed]

25. Shirling, E.B.; Gottlieb, D. Methods for characterization of Streptomyces species. J. Syst. Evol. Microbiol. 1966, 16, 313-340. [CrossRef]

26. Prapagdee, B.; Kuekulvong, C.; Mongkolsuk, S. Antifungal potential of extracellular metabolites produced by Streptomyces hygroscopicus against phytopathogenic fungi. Int. Boil Sci. J. 2008, 4, 330-337. [CrossRef] [PubMed]

27. Vargas-Garcia, M.C.; Suarez-Estrella, F.; Lopez, M.J.; Moreno, J. In vitro studies on lignocellulose degradation by microbial strains isolated from composting processes. Int. Biodeterior. Biodegrad. 2007, 59, 322-328. [CrossRef] 
28. Chefetz, B.; Hatcher, P.G.; Hader, Y.; Chen, Y. Chemical and biological characterization of organic matter during composting of municipal solid waste. J. Environ. Qual. 1996, 25, 776-785. [CrossRef]

29. Storer, D.A. A simple high sample volume aching procedure for determination of soil organic matter. J. Soil Sci. Plant Anal. 1984, 15, 759-772. [CrossRef]

30. Brainina, K.Z.; Stozhko, N.Y.; Belysheva, G.M.; Inzhevatova, O.V.; Kolyadina, L.I.; Cremisini, C.; Galletti, M. Determination of heavy metals in wines by anodic stripping voltammetry with thick-film modified electrode. Anal. Chem. Acta 2004, 514, 227-234. [CrossRef]

31. Van Soest, P.J.; Robertson, J.B.; Lewis, B.A. Methods of dietary fiber, neutral detergent fiber and non-starch polysaccharides in relation to animal nutrition. J. Dairy Sci. 1991, 74, 3583-3597. [CrossRef]

32. Nigam, P.; Singh, D. Solid-state (substrate) fermentation systems and their applications in biotechnology. J. Basic Microbiol. 1994, 34, 405-423. [CrossRef]

33. Abdulkhair, W.M. Chitinolytic activity of highly halotolerant Streptomyces tendae against Fusarium oxysporum PTK2. Afr. J. Biotechnol. 2012, 11, 15523-15532. [CrossRef]

34. McCarthy, A.J. Lignocellulose-degrading actinomycetes. FEMS Microbiol. Lett. 1987, 3, 145-163. [CrossRef]

35. Abdulla, H.M.; El-Shatoury, S.A. Actinomycetes in rice straw decomposition. J. Waste Manage 2007, 27, 850-853. [CrossRef] [PubMed]

36. Molla, A.H.; Fakhrul-Razi, A.; Abd-Aziz, S.; Hanafi, M.M.; Roychoudhury, P.K.; Alam, M.Z. A potential resource for bioconversion of domestic wastewater sludge. Bioresour. Technol. 2002, 85, 263-272. [CrossRef]

37. Castillo, M.P.; Ander, P.; Stenstrom, J. Lignin and manganese peroxidase activity in extracts from straw solid substrate fermentations. J. Biotechnol. Technol. 1997, 11, 701-706. [CrossRef]

38. Ghose, T.K. Measurement of cellulose activities. J. Pure Appl. Chem. 1987, 59, 257-268. [CrossRef]

39. Tan, Y.H.; Wahab, M.N. Extracellular enzyme production during anamorphic growth in the edible mushroom, Pleurotus Sajor-Caju. World J. Microbiol. Biotechnol. 1997, 13, 613-617. [CrossRef]

40. Veeken, A.H.M.; Adani, F.; Nierop, K.G.J.; de Jager, P.A.; Hamelers, H.V.M. Degradation of bio-macromolecules during high rate composting of wheat straw-amended feces. J. Environ. Qual. 2001, 30, 1675-1684. [CrossRef]

41. Lee, I.B.; Kim, P.J.; Chang, K.W. Evaluation of stability of compost prepared with Korean food wastes. J. Soil Sci. Plant. Nutr. 2002, 48, 1-8. [CrossRef]

42. Wenzel, M.; Schonig, I.; Berchtold, M.; Kampfer, P.; Konig, H. Aerobic and facultative anaerobic cellulolytic bacteria from the gut of the termite Zootermopsis angusticollis. J. Appl. Microbiol. 2002, 92, 32-40. [CrossRef] [PubMed]

43. Thawai, C.; Tanasupawat, S.; Itoh, T.; Suwanborirux, K.; Suzuki, K.; Kudo, T. Micromonospora cburnea sp nov., isolated from a Thai peat swamp forest. Int. J. Syst. Evol. Microbiol. 2005, 55, 417-422. [CrossRef] 